\title{
The influence of storage temperature and moisture content on seed viability in pepper (Capsicum annuum L)
}

\author{
S Lotito, L Quagliotti * \\ DIVAPRA Plant Breeding and Seed Production, University of Turin, via Giuria 15, 10126 Turin, Italy
}

(Received 16 June 1992; accepted 8 December 1992)

\begin{abstract}
Summary - The viability of pepper (Capsicum annuum L) seeds kept at 9 combinations of temperature and seed moisture was checked by germination tests over a period of 16 months. The relationship between storage environment and seed survival was evaluated by a viability equation, whose constants were determined by probit analysis and least squares method. In this way it is possible to predict the percentage of germination of pepper seeds, but its validity applies only to non-extreme storage conditions. An example is given.
\end{abstract}

Capsicum annuum $=$ pepper $/$ seed viability $/$ seed moisture $/$ seed storage $/$ storage temperature

Résumé - L'influence de la température de conservation et de la teneur en eau sur la viabilité des semences de poivron (Capsicum annuum L). On a étudié l'effet de 9 combinaisons de température et de teneur en eau sur le maintien de la viabilité chez des semences de poivron cv Quadrato d'Asti. Cette viabilité a été contrôlée pendant 16 mois par des essais de germination répétés périodiquement en boites de Petri selon les règles de I'ISTA : dénombrement des plantules normales après 14 jours à l'alternance $20^{\circ} \mathrm{C}$-obscurité $(16 \mathrm{~h}) / 30^{\circ} \mathrm{C}$-lumière $(8 \mathrm{~h})$. La relation entre les facteurs considérés et le temps de survie des graines a été évaluée au moyen d'une équation de viabilité. Les constantes de celle-ci ont été déterminées par une analyse de probits et la méthode des moindres carrés, compte tenu de la viabilité initiale de l'échantillon utilisé. L'équation permet de prédire le pourcentage de germination des graines de poivron après un certain temps, pourvu que les conditions de conservation ne soient pas extrêmes. Un exemple d'application de l'équation est donné.

Capsicum annuum = poivron / viabilité des graines / teneur en eau des graines / température de conservation / stockage de semences

\section{INTRODUCTION}

Good storage of the seeds is an important matter, especially if they have a high technological value, such as vegetable crops, or if there are production difficulties, as in the developing countries.

Several interesting studies have been carried out on the effects of time and of storage environment on viability and vigour of pepper seeds (Bottaro and Quagliotti, 1986; Quagliotti, 1986; Belletti et al, 1990).

Unfortunately, the results do not permit prediction of the behaviour of pepper seeds under storage conditions different from those used in these experiments. But there are a number of circumstances in which it is important to be able to predict the environmental effects on seed lot longevity; for example, germplasm banks must maintain accessions and gene pools in viable conditions for as long as possible.

The majority of crop species show 'orthodox' seed characteristics (Roberts, 1973), that is, their longevity is prolonged by a reduction in moisture content and temperature (Ellis and Robert, 1980a).

The frequency of individual deaths with time in a population, stored in constant conditions, is described by the normal distribution:

* Correspondence and reprints 


$$
y=\{1 / \sigma \sqrt{2} \bar{\pi}\} \exp \left\{-(p-\bar{p})^{2} / 2 \sigma^{2}\right\}
$$

where $y$ is the relative frequency of deaths occurring at time $p, \bar{p}$ is the mean viability period, and $\sigma$ is the standard deviation of the distribution of deaths with time. Thus, the seed survival curve (percentage viability plotted against time) is a cumulative normal distribution of negative slope, which becomes a straight line if percentage values are transformed to probits. When several constant conditions are compared, the mean viability period and the standard deviation vary in the same proportion, that is:

$$
\sigma=\mathbf{K}_{\sigma} \bar{p}
$$

where $\mathbf{K}_{\sigma}$ is a constant for each species.

This trend has been demonstrated in many species (Roberts, 1972; Roberts and Abdalla, 1968; Ellis et al, 1982; Belletti et al, 1991).

Without taking into account the effect of oxygen, which is not completely known, the pattern of viability under given combinations of storage temperature and moisture content can be defined by an equation which takes into account the initial quality of the seeds, according to their genotype and to the prestorage conditions.

According to Ellis and Roberts (1980a), the equation can be written in 2 ways, of which the simpler is :

$$
v=\mathbf{K}_{i}-p / 10^{\left(\mathbf{K}_{L}-\mathbf{C}_{1 m}-\mathbf{C}_{2 t}\right)}
$$

This equation relates percentage viability, $v$, (expressed in probit) at any time $p$ (expressed in days), to any combination of moisture content, $\mathrm{m}$, (percent of fresh weight basis), and temperature $t\left({ }^{\circ} \mathrm{C}\right) . \mathbf{K}_{L}, \mathbf{C}_{1}$ and $\mathbf{C}_{2}$ are constants specific to the species, but independent of genotype and initial seed quality. $\mathbf{K}_{i}$ is specific to the seed lot and is a measure of initial quality.

The purpose of this paper is to report the results of estimation of viability constants for pepper.

\section{MATERIALS AND METHODS}

The cv Quadrato d'Asti rosso, from a commercial provenance. The initial lot characteristics were: percentage of germination (PG): $89 \%$, moisture content (MC): $7.2 \%$.

The seed were subjected to several moisture contents by humidification with wetted filter paper in sealed boxes, at $15-18^{\circ} \mathrm{C}$, for a period ranging from $30 \mathrm{~s}$ to $2 \mathrm{~h}$.

Three moisture levels were reached in different times: $10.2 \%, 15.6 \%$ and $20.8 \%$. To permit a uniform distribution of moisture, the seeds were kept, after sealing in aluminium bags, for $48 \mathrm{~h}$ at $10^{\circ} \mathrm{C}$. A moisture content control was performed after this treatment.

Subsequently, the seeds were stored in sealed aluminimum bags, at temperatures of $25^{\circ} \mathrm{C}, 35^{\circ} \mathrm{C}$ and $45^{\circ} \mathrm{C}$. A total of 9 temperature-moisture combinations were analysed:

$$
\begin{aligned}
& 25^{\circ} \mathrm{C}: 10.2 \%, 15.6 \% \text { and } 20.8 \% \text {; } \\
& 35^{\circ} \mathrm{C}: 7.2 \%, 10.2 \%, 15.6 \% \text { and } 20.8 \% \text {; } \\
& 45^{\circ} \mathrm{C}: 7.2 \% \text { and } 15.6 \% \text {. }
\end{aligned}
$$

No attempts were made to modify the atmosphere composition inside the containers.

Samples of stored seeds were taken and put to germinate periodically, depending on the storage conditions. The frequency of sampling ranged from 1-60 d.

The determination of moisture content was performed on thermostatic stove at $105^{\circ} \mathrm{C}$ for $16 \mathrm{~h}$ (ISTA, 1985). Again, in this case, the size of the sample analysed was increased: 4 replicates instead of 2 .

All the determinations of PG were performed in Petri dishes, with filter paper as substratum, according to ISTA Rules ie count of normal seedling after $14 \mathrm{~d}$ alternating: $20^{\circ} \mathrm{C}$ - obscurity $(16 \mathrm{~h}) / 30^{\circ} \mathrm{C}$ - light $(8 \mathrm{~h})$ (ISTA, 1985). To reduce the sampling error, the tests were performed on 1000 seeds, 4 replicates of 250 seeds, rather than 400 seeds, 4 replicates of 100 seeds. This should permit a better estimation of equation [3] parameters. In fact, as demonstrated by Ellis and Roberts (1980a), because of the nature of the normal distribution, even small differences in percentage germination at high values can have a large effect on the value of $\mathbf{K}_{i}$.

By probit analysis (Finney, 1962) for each storage condition, the half viability period, $p_{50}$ (the time taken for viability to fall to $50 \%$ ), and the standard deviation, $s$, of the distribution of seed deaths with time were determined.

The constants $\mathbf{K}_{L}, \mathbf{C}_{1}$ and $\mathbf{C}_{2}$ were determinated by using least square method. The seed lot constant $\mathbf{K}_{i}$ was calculated as a reciprocal function of value $\mathbf{K}_{S}$ (the estimator of $\mathbf{K}_{\sigma}$, eq [2]).

\section{RESULTS}

Under all the storage conditions, the frequency distribution of seed deaths with time was normally distributed. This implies that the seed survival curves showed a symmetrical sigmoid distribution which can be described by a negative cumulative normal distribution.

In 2 storage conditions $\left(25{ }^{\circ} \mathrm{C}-10.2 \%\right.$ and $35^{\circ} \mathrm{C}-7.2 \%$ ) it was not possible to determine the 
values $p_{50}$ and $s$, since the loss in viability after 480 d was insufficient to construct survival curves. The values of the parameters were calculated for the other seven treatments investigated. Values of $p_{50}$ ranged from $1.2-140 \mathrm{~d}$ (fig 1), while values of $s$ ranged from $0.9-117 \mathrm{~d}$.

The values of the constant of eq [3] were as follow: $\mathbf{K}_{i}=6.2$ (expressed as probit value); $\mathbf{K}_{L}=$ 6.063 (significant with $p<0.01$ and $s e=1.012$ ), $\mathbf{C}_{1}=0.111$ (significant with $p<0.05$ ) and $s e=$ 0.031 ) and $\mathbf{C}_{2}=0.088$ (significant with $p<0.01$ and $s e=0.019$ ).

\section{DISCUSSION}

The results obtained in our experiment demonstrate that in the ageing of pepper seeds the relationship between temperature, moisture content and viability is fairly well described by the improved equation given by Ellis and Roberts.

Some limits for validity of viability equation exist: there is a low moisture content limit, below which the equation [3] is no longer applicable; in fact, a further reduction in moisture content no longer increases seed longevity. This limit has been found to vary within species. Values of 2$3 \%$ of moisture content give a rough indication of this limit (Ellis et al, 1988). Moreover, damage can occur during the drying process, particularly,

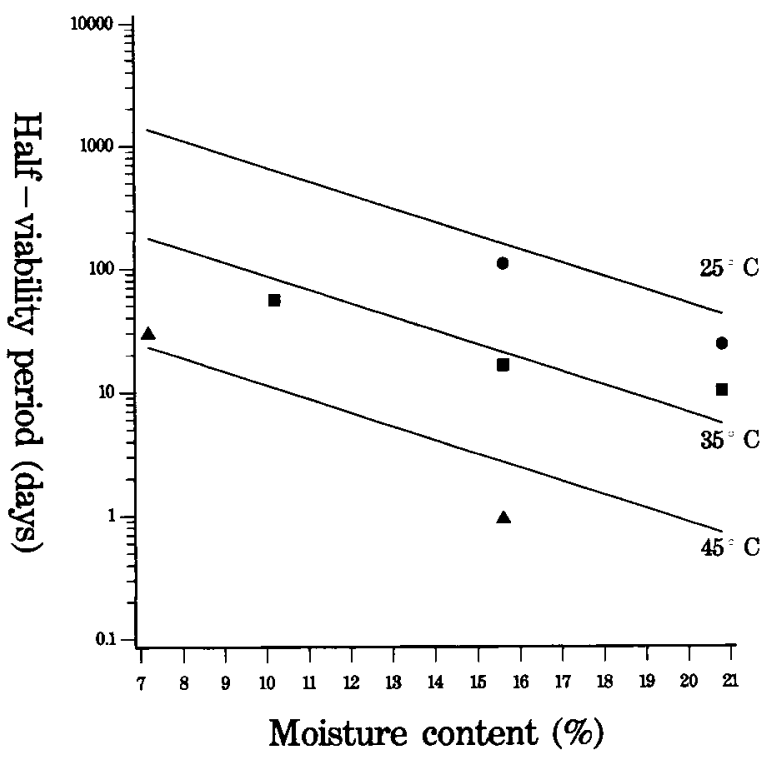

Fig 1. The relationship between half-viability period and moisture content of pepper (Capsicum annuum L) cv Quadrato d'Asti Rosso, hermetically stored at the following constant temperatures: $25^{\circ} \mathrm{C}$ (circle), $35^{\circ} \mathrm{C}$ (square) and $45^{\circ} \mathrm{C}$ (triangle). Half-viability period is plotted on a logarithmic scale, and the fitted curves are those according to equation [3] and the viability constant values reported in the text. if high temperature are used for drying (Ellis and Roberts, 1980a; Nellist, 1981), with the result that the viability could be lower than that predicted. There is also an upper limit, termed critical (Ibrahim et al, 1983), beyond which the longevity of the seeds increases with the increase in their moisture content, but only if oxygen is present.

The application of the simpler of the $2 \mathrm{im}$ proved equations (Ellis and Robert, 1980a) should only be used to predict longevity within the range over which the constants were determined. Extrapolation to higher or lower moisture contents will under-estimate seed longevity due to the slightly concave log-linear relationship between longevity and moisture content (Ellis and Robert, 1980b). This is why as light underestimation was detected when the parameters calculated were tested on a «California Wonder» seed lot, stored for 33 months at $25^{\circ} \mathrm{C}$ (in thermostatic freezer), with an MC of $5.5 \%$. The viability predicted values were lower (maximum $1 \%$ ) than real $P G$, after 12, 18, 24 months of storage.

For a wider range of storage conditions, more extreme combinations of temperature-moisture should be included in the analysis; this should permit estimation of the parameters of the improved equation that include the logarithmic transformation of the moisture term and the negative quadratic temperature term (Ellis and Robert, 1980a).

Within the ranges of temperature and moisture studied the simple equation is adequate.

For practical use, the results of this paper can be used in the following way:

with an initial $P G$ of $90 \%$ the $\mathbf{K}_{j}$, ie the probit value of $P G$, can be easily obtained using statistical tables (Fisher and Yates, 1957), from which a $\mathbf{K}_{i}$ of 6.28 is obtained. Now, when storing the seeds with an $\mathrm{MC}$ of $8 \%$ and a constant storage temperature of $27^{\circ} \mathrm{C}$, the equation terms after $365 \mathrm{~d}$ of storage will be:

$$
v=6.28-365 / 10^{(6.063-0.111 \cdot 8-0.088 \cdot 27)}=5.7
$$

From statistical tables it is possible to retransform the probit value into percentage of germination, thus obtaining a $P G$ value of $76 \%$.

The fit can be significantly improved by estimating the $\mathbf{K}_{i}$ parameter of the lot under analysis with the use of a sample size larger than 400 seeds or performing probit analysis of serial germination tests in a rapid-ageing test (Ellis and Robert, 1979). 


\section{REFERENCES}

Belletti P, Lanteri S, Lotito S (1991) The influence of temperature and moisture on seed ageing in Iceland poppy (Papaver nudicaule L). Sci Hortic 48, 153-158

Belletti P, Lanteri S, Nassi MO, Quagliotti L (1990) Factors related to the cryopreservation of pepper and eggplant seeds. Adv Hortic Sci 4, 118-120

Bottaro S, Quagliotti L (1986) Results of an experiment of six years storage of pepper seeds. Capsicum Newslett 5, 61-62

Ellis RH, Roberts EH (1979) Towards a rational basis for testing seed quality. In: Seed Production (Hebblethwaite PD, ed) Butterworths, London, 605-635

Ellis RH, Roberts EH (1980a) Improved equations for the prediction of seed longevity. Ann Bot 45, 13-30

Ellis RH, Roberts EH (1980b) The influence of temperature and moisture on seed viability period in barley (Hordeum disticum $\mathrm{L}$ ). Ann Bot 45, 31-37

Ellis RH, Osei-Bonsu K, Roberts EH (1982) The influence of genotype, temperature and moisture on seed longevity in chickpea, cowpea and soya bean. Ann Bot 50, 69-82

Ellis RH, Hong TD, Roberts EH (1988) A low moisture content limit to logarithmic relations between seed moisture content and longevity. Ann Bot 61, 405408

Finney DJ (1962) Probit Analysis. Cambridge Univ Press, London, 2nd edn
Fisher RA, Yates F (1957) Statistical Tables. Oliver and Boyd, Edinburgh, 6th edn

Ibrahim A, Roberts EH, Murdoch AJ (1983) Viability of lettuce seeds. II. Survival and oxygen uptake in osmotically controlled storage. J Exp Bot 34, 631-640

International Seed Testing Association (1985) International rules for seed testing. Annexes. 1985. Seed Sci \& Technol 13, 356-513

Nellist ME (1981) Predicting the viability of seeds dried with heated air. Seed Sci \& Technol 9, 2, 439-455

Quagliotti $L$ (1986) Seed storage behaviour in pepper. In: VI Eucarpia Meeting Genetics and Breeding of Capsicum and Eggplant. Zaragoza, 57-59

Roberts EH (1972) Storage environment and the control of viability. In: Viability of Seeds (Roberts EH, ed) Chapman and Hall, London, 14-58

Roberts EH, Abdalla FH (1968) The influence of temperature, moisture and oxygen on period of seed viability in barley, broad beans and peas. Ann Bot 32 , 97-117

Roberts EH (1973) Predicting the storage life of seed. Seed Sci \& Technol 1, 499-514

Villiers TA (1975) Genetic maintenance of seeds in imbided storage. In: Crop genetic Resources for Today and Tomorrow (Frankel OH, Hawkes JG, eds) Cambridge, Cambridge Univ Press, 297-316 